of being with is against the course of the natural drainage of the country. Of course it is no new thing that cholera hugs the banks of a stream; but it has never happened that an epidemic of cholera commenced in the Himalayas or Upper Provinces and spread gradually down the Ganges, Jumna, or Indus ; its advance has been exactly opposite.

Profesaor Koch, misled no doubt by incorrect information, has attributed the improvement in the health of the garrison at Fort William, Calcutta, to the introduction of a pure water-supply; but the fact is that an Order in Council exists refusing to sanction the necessary expenditure for its introduction, in consequence of the remarkably good bealth which the Fort William garrison had then been enjoying for several years past. The town water was subsequently introduced but there was no such causal connexion between the two things as has been alleged. There are, moreover, some facts within my knowledge connected with the prevalence of cholera on board some of the Assam steamers, and the town and district of Dacca, which would indicate how cautious we should be before considering that cholera infection through a specifically contaminated water is a demonstrated fact.

This communication has already extended to a wearisome length, therefore I will finish what I have to say next week if you will kindly grant me the necessary space. I am, Sir, yours obediently,

September, 1884. J. A. Marston, Deputy-Surgeon General, A.M.D.

\section{"THE METAPHYSICS OF COMTE."} To the Editor of THE LANCET.

SrR,-The tone of Mr. FitzPatrick's letter makes me fear that I did wrong in using the not very elegant term "rubbishy" to qualify metaphysics. But the context would show that the worthlessness of rubbish was ascribed by me to metaphysics in general, and not only to the mystical latest phases of Comte, which are at least as like metaphysics as one fog is like another.

I certainly did not mean to speak slightingly of Comtists, and am very sorry if I seemed to do so. No mere passer-by would cast a reflection ever so remote and momentary upon the distinguished group of men known as Comtists, or Positivists. Even a wayfaring man must be moved by the aspect of a somewhat forlorn group worshipping Humanity in the cold shade of public neglect. Nay, it is even quite touching to witness their almost simple disregard of that reeiprocity which more numerous and ordinary worshippers commonly have an $\in$ ye to.

The Comtists made science into what they call philosophy, and philosophy into what they call religion, and having done so they worship. They worship humanity, the source of their undivine religion and science. Very few people join in the worship; and it is curious to me that the Comtists do not see why this is. They do not appear in the least to appreciate the greatest and first of truths which is at the foundation of all religion-the truth, namely, that there must be a reciprocity between worshipper and worsbipped. The reciprocity is, indeed, necessarily a close one. Even Pagans have seen this greatest of truths. Cicero clearly perceived it. He remarks that the deity of elephants would have a proboscis. But the correspondence of worshipper and worshipped may be ground too sacred to admit of playful treatment. Nevertheless, I may remark how the intensely personal Jew worshipped a correspondingly personal God. Intense individuality required uncompromising monotheism. The Jew has never been able to accept Christ's simple summary of the Commandments. The intensely personified God who reciprocated to the intense ego of the Jew was even supposed by the Jew to grow jealous about him. But Humanity will never grow jealous about the Comtists, however their clever high priest, $\mathrm{Mr}$. Frederick Harrison, may flirt with the Unknowable quite openly before the very eyes of Humanity in the Nineteenth Century and The Times. The weakness of the Comtists philosophy-religion, which is neither religion nor philosophy, but which at any rate worships Humanity, is that there will never be any reciprocity of worshipper and worshipped, I must leave it to Mr. Harrison and to Mr. Spencer to settle for Mr. FitzPatrick whether Comtism includes the whole Spencerian system, metaphysics and all. It is plain to anyone reading Mr. Harrison's letter in The Times of this week that Pusitivists do not see themselves quite as others see them. One cannot be sur. prised. The "giftie" of seeing ourselves as others see us would belong rather to Relativists than Positivists, But Mr. FitzPatrick has been acquainted with the distinguished group of Comte's followers, and he must be aware that the "latest phases" of Comte became mystical and obscure, and left the safe ground of five-sense science, and undertook to deal objectively with the subjective aspect of life, and that in this departure he was not followed by all his followers, sinall as the distinguished group has always been. Was not Littre rather than Comte the Paul of the Positive system? And is not Mr. Frederick Harrison now a kind of melodramatic Athanasius, declaring the Positive polity with its human subjective synthetic side to be ómoviolos with the awful primitive abstractions of Positive Science. Oae, indeed, can easily foresee fundamental divisions amongst the Comtists. But such divisions will never reach great dimensions through the numbers involved. To be a Positivist your brain must preponderate over your heart-a result obtainable either through much brain or little heart; and either of these alternatives will disqualify you for a wide religious success amongst the multitudes who compose humanity. Mr. Frederick Harrison has evidently much brain. The little Comtists whose qualification for the Positive philosophy consists in little heart are in even a more hopeless case than Mr. Harrison as to the prospect of attracting the attention of their divinity.

I am, Sir, yours truly

Finsbury-circus, E.C., Sept. 15th, 1884.

W. MoxoN.

CONGENITAL SACRAL TUMOUR: A CORREC. TION FOR THE "SYSTEM OF SURGERY."

\section{To the Editor of THE LANCET.}

Sir,-My attention has been called by $\mathrm{Mr}$. Charles Hawkins to an unaccountable error in an article of mine in the "System of Surgery." May I ask you to allow me space to make the necessary correction? The passage is in vol. iii., p. 781, of the new (third) edition, in the article on Surgical Diseases of Childhood. Speak ing of "congenital sacral tumour," and of the danger of operations on such tumours, I say, "This remark is illustrated by a preparation in St. George's Hospital Museum consisting of a number of irregular pieces of bone from a con genital tumour removed by Sir B. Brodie from the sacral region. The operation proved fatal." I cannot explain how such a misrepresentation could have crept into my work, since I had previously, in my book on "Surgical Diseases of Children" (second edition, p. 20) quoted from Mr. Hawkins's paper in the Path. Soc. Trans., vol. iii. p. 447, the following account of the real history of the case in Sir B. Brodie's words:- "Contrary to my advice, a surgeon made an incision into the tumour which not only served no useful purpose, but left him in a worse state than he was before. Different cysts suppurated, discharging pus and adhesive fluid. Sometimes a collection of fluid and pus pressed on the rectum occasioning a difficulty of expulsion of fæces, and then discharging its contents into the bowel. After this be was always in a state of greater or less suffering. He lost flesh had occasional attacks of fever, and at last he sank and died." Thus my statement is erroneous in three particulars. 1. Sir B. Brodie far from having removed the tumour always advised the patient strongly to permit no interference with it. 2 . The tumour was never really removed; the "other surgeon" only made an incision into it, when it was inflamed in consequence of the patient having fallen on it. 3 . The pieces of bone in the preparation were removed, not during life, but by Mr. Hawkins in post-mortem examination.

I have thought it desirable to correct the error, which indeed ought never to have got in to the text, or ought to have been corrected in the second edition of the System. The main conclusion, however, which I attempt to enforce in the article is unaffected by my blunder-viz., that such tumours should only be operated on when the surgeon believes that he can extirpate the whole tumour, and even then not without an adequate motive, since the operation is always a very formidable one. I am, Sir, yours truly.

Great Cumberland.place, Sept. 11th, 1884. 
THE EXAMINATION OF SURGEONS-MAJOR. To the Editor of THE LANCET.

SIR,-Pressure of business has prevented my ere this asking you the favour of a space in your valuable journal for the few following remarks, in addition to the many already expressed, upon the subject of submitting surgeonsmajor in the army over twenty years' service to a qualifying examination for promotion to the rank of brigade-surgeon (vide Army Circular, August 1st, 1884). The inadvisability of any examination for officers of such seniority appears to me apparent, having regard both to the prestige of the service and to the amour propre of the profession. This presumably is a military question, for which some imaginary precedent may supply the apology. Not even so much excuse or extenuation can be claimed for paragraph 9 , by which I see it is intended that these elderly victims are literally, in more senses than one, to be put through their $\mathrm{ABC}$, as I notice alphabetical clauses through two-thirds of the alphabet, terminating at letter $O$, which forms the culminating point of the whole absurdity. See paragraph 9, clause 0: "Questions on operative surgery and practical medicine will also form part of this examination." But one parallel could be found for examining in such subjects professional men of a quarter of a century's seniority-viz., to subject all lieutenant-colonels in the army to an examination in the goose-step as a qualifying test of their fitness for promotion to the rank of colonel. Indeed, my allusion to the manners and customs of the feathered tribe appears suggestively applicable in tracing the present steps taken by the originators of this circular. This does not explain, how. ever, the unaccountable deviation on the Director-General's part from the high order of intellect and capacity with which he has hitherto distinguished his present position, and if, contrary to his convictions, he has allowed himself to be influenced, the fact is only the more deplorable. The assignable object of these innovations is a desire to prove the efficiency of the department ; but why delay that demonstration for twenty years? Were an examination necessary for such a purpose, its utility would be more marked at the commencement of an officer's career than towards its close. If a man has been efficient during twenty years' service, there is but scant necessity for proving the fact at the end of that term; and if he has hitherto been incompetent, it is late to remedy the evil. By all means subject officers to a rigid and most searching examination upon the widest range of professional subjects, between the ranks of surgeons and surgeons-major. From that much benefit would most probably accrue. But an officer practising for over twenty years is as unlikely to profit in the smallest degree from an examination as he is certain to be embittered against a service which could subject him to so unnecessary an indignity.

By paragraph 11 we are informed as to the nature and means of this inquisitorial revival. "It is to be in part by printed papers and in part viva voce. The Board will enter so far into the subject-matter of each head selected for vivo voce examination as to show that the officer's knowledge has been fully tested." By all means. Only primarily let the Board's knowledge "be fully tested" as to its capability of pronouncing upon the practice and experience of officers who quite probably are as worthy of confidence as would be the opinion of those exalted personages forming the Board. By paragraph 12 I see this Board is "carefully to record all questions asked and answers received, and to send the record to the Director-General" But such a record must materially improve or deteriorate in merit according to the capacity and reliability of the source through which it is transmitted. To conclude: The papers will then be submitted to another Board, likewise of experienced officers, who in their turn are to pronounce upon the competence of the officer. For the second time the colouring given to that officer's proficiency would be deeply tinged by the prevailing hues of the Board's capability for transmitting the treble-distilled matter originally received from the unfortunate victim. He consequently must be largely dependent, not upon bis own brains, but upon what could not obviously be a certain maximum quantity of that commodity in the possession of those relays of experienced individuals, always apparently unquestionable in their description. One naturally wonders whoare to form this all-important tribunal. Finst, if civilians, an inevitable slur is cast upon the proficiency of the department. Secondly, if men in the same service, how can it be ascertained that they know more about the subject than those they are pronouncing upon? Thirdly, will the presiding genii be called from amongst those fortunate mushrooms who spring suddenly to the surface and into office, having been grown in the forcing soil of an effete favouritism? Then, indeed, the whole injustice is not left without a copingstone. But, as though there were any apprehension that the entire fiasco might not be rendered quite complete, we are informed that "the examination will be optional." Is it to be inferred from this that there is a lurking suspicion in the minds of the authorities that the veteran doctor would prefer bringing his grey hairs in sorrow, as a surgeon-major, to the grave, rather than face the alternative of being turned into a metaphorical shuttlecock, to be battledored from Board to Board, and from the A B C to the Omega of his profession? A very heartfelt sympathy with, and in terest in, the department, gathered from personal experience in the services, must be my apology to you for so inconsiderately trespassing on your space.

I am, Sir, your obedient servant,

Dublin, Sept. 16th, 1884 W. I. WHEELER, F.R.C.S., Surgeons, Ireland.

\section{THE CHOLERA.}

To the Editor of THE LANCET.

SIR, - The continued spread of cholera on the Continent makes it imperative on the part of medical officers to take extra precautionary measures to prevent its outbreak in this country, and especially in London. When cholera first appeared in France, the metropolitan authorities freely used disinfectants to street gullies and gratings, so that poisonous gases from putrefying matter were in a measure destroyed. It is not only gratings, gullies, dustbins, urinals, and receptacles for dust that require special attention at this time of the year, but the greatest danger exists in the branch drains leading from buildings to sewers in the streets. These are to some extent not under the control of vestries, and the inlets into sewers are often closed, and from these gases of the most poisonous nature are produced. In these branch drains disinfectants should be freely employed during the next two months. I am aware that many of the medical profession treat very lightly the theory that gases from putrefying matter are the principal agents in generating and transmitting zymotic disease; but to those who have investigated the question, it is not one of theory, but of fact. Previous to the cholera outbreak on the Continent, small-pox was very prevalent in London, but the free use of disinfectants as a preventive against cholera had the effect of stopping the small-pox epidemic.

September, 1884. I am, Sir, yours faithfully, R. H. REEVES,

\section{LORD TENNYSON AND THE SURGEON. To the Editor of THE LANCET.}

SIR,-Even professing Christians are liable to imagine one another to be monsters of iniquity, and this is due to ignorance, for when placed on the same platform in some effort to benefit humanity, they learn to esteem one another. Probably Lord Tennyson is ignorant of doctors and their work, while Dr. Moxon may be ignorant of the incessant charitable visits of the Poet Laureate to his poor neighbours. It may be that Lord Tennyson was accustomed to distribute tracts in some village hospital, and met with a surgeon whose time did not allow him to pay sufficient, or, at least, desired, attention to the distinguished visitor. We ought never to judge hastily, and while surgeons may be doing everything in their power to relieve and cure their patients and deserve all honour for their sympathy and kindness, they must respect and honour the man who throws open his garden to the waifs of the street and at his own expense takes a crowd of little convalescents or street Arabs from the slums of London to indulge them with games and regale them with fruit on his own lawn, while he instructs them by reciting pieces of poetry and reading Gospel stories to them. I do not know any thing of Lord Tennyson's deeds of charity, but no doubt his biographer will relate them. It is possible, 